\title{
Microbial communities in a coastal cave: Cova des Pas de Vallgornera (Mallorca, Western Mediterranean)
}

\author{
Antoni Busquets ${ }^{1}$, Joan J. Fornós ${ }^{2 *}$, Freddy Zafra ${ }^{1}$, Jorge Lalucat ${ }^{1,3}$, and Antoni Merino ${ }^{4}$ \\ ${ }^{1}$ Departament de Biologia, Universitat de les Illes Balears. Ctra. Valldemossa km 7,5, 07122 Palma, Illes Balears, Spain \\ ${ }^{2}$ Departament de Ciències de la Terra, Universitat de les Illes Balears. Ctra. Valldemossa km 7,5, 07122 Palma, Illes Balears, Spain \\ ${ }^{3}$ IMEDEA (CSIC-UIB). Esporles, Mallorca, Illes Balears, Spain \\ ${ }^{4}$ Grup Espeleològic de Llubí, FBE, Illes Balears, Spain
}

\begin{abstract}
As a part of an ongoing project on the role of microbes in the biogeochemistry of Majorcan caves, the species diversity of microbial communities present in cave pools of anchialine waters in the Cova des Pas de Vallgornera (Mallorca, Western Mediterranean) is investigated by a culture-dependent method. Two-hundred and forty-eight strains isolated from this characteristic littoral karst cave environment are identified by whole-cell-MALDI-TOF mass spectrometry and phylogenetically by $16 \mathrm{~S}$ rRNA gene sequences. Total cell counts and species diversity of the bacterial communities decrease with the distance to the entrance of the cave and to the sea. Strains are mainly identified as members of the Gammaproteobacteria and Actinobacteria. Around $20 \%$ of the isolates are able to precipitate carbonates. Calcite is the predominant phase, growing in all the precipitates, although struvite is also found in one Pseudomonas and in one Aspergillus cultures. Differences in crystal habit and growth are observed according to the bacterial species promoting the precipitates. Bacteria associated with multicolored ferromanganese deposits, present in several parts of the cave, are also studied and are identified as Pseudomonas benzenivorans and Nocardioides luteus. The preponderance of Pseudomonas species and the possible contribution of bacteria in calcite deposition are discussed.
\end{abstract}

Keywords: microbial community; fungi; brackish pools; anchialine; carbonate precipitates; ferromanganese deposits; littoral cave; Mallorca

Received 31 October 2013; Revised 6 May 2014; Accepted 10 May 2014

Citation: Busquets A., Fornós J.J., Zafra F., Lalucat J., and Merino A. 2014. Microbial communities in a coastal cave: Cova des Pas de Vallgornera (Mallorca, Western Mediterranean). International Journal of Speleology, 43 (2), 205-216. Tampa, FL (USA) ISSN 0392-6672 http://dx.doi.org/10.5038/1827-806X.43.2.8

\section{INTRODUCTION}

The presence of carbonates in the deposits that make up the island of Mallorca, the largest of the Balearic Archipelago, have been subjected to longterm karstification processes that have generated a well-known variety of specific landforms and caves (Fornós et al., 2002; Gràcia et al., 2011). Apart from these, a wide range of intermingled karst and littoral processes were reported in the coastal karst areas of the island (Ginés \& Ginés, 1986), an environment that is affected by changes in sea level and the subsequent shifts of the shoreline, introducing a chronological pattern that is directly controlled by the Pleistocene fluctuations of both climate and sea elevation (Tuccimei et al., 2006; Dorale et al, 2010; Ginés et al., 2012).

The deposition of speleothems is an active process happening in most karst regions around the world
(Fairchild \& Baker, 2012). In Mallorca, a great variety of speleothems are common occurrences within the different cave environments of the island, especially in the littoral caves. Although there is an abundant bibliography covering this topic (Merino et al., 2011a, 2011b, 2014a, 2014b) and considering the widely accepted issue that microorganisms, mainly bacteria, may contribute to the precipitation of carbonates and other minerals (Ehrlich, 2002; Melim et al., 2009; Jones, 2010), it is quite surprising that this topic is so little covered in the Mallorcan karst literature.

There are many interesting research topics related with geomicrobiological studies. One of them is the active role of microorganisms in carbonate precipitation in speleothems (Barton \& Northup, 2007). There are numerous reports in the scientific literature demonstrating in laboratory experiments that bacteria contribute to the precipitation of different minerals (Van Lith et al., 2003; Rivadeneyra et al., 
2004; among others) and sedimentologic microbial accretions from different marine environments have been also observed in the fossil record (Tucker \& Wright, 1990; Sánchez-Navas \& Martín-Algarra, 2001; Cailleau et al., 2005). It is not clear what the mechanisms are for carbonate precipitation by bacteria in natural habitats (Castanier et al., 1999; Ehrlich, 2002), nor the role, active or passive, that bacteria play in the biomineralization process or if they can directly influence the formation of a specific mineralogical precipitate (Bosak et al., 2004). The optimal conditions for bacterial precipitation of carbonate minerals are influenced by abiogenic factors, especially the salt concentration and ionic composition of the medium (Fernández-Diaz et al., 1996; Rivadeneyra et al., 2006).

In a first step to elucidate the role of bacteria in the biogeochemistry of Mallorcan caves, we initiated the characterization of bacterial communities present in cave pools of brackish waters in the Cova des Pas de Vallgornera, a characteristic anchialine cave environment, in the sense of Sket (2005), where seawater bodies along the coast influence the subterranean habitats inhabited by several species of the littoral karst. These habitats that are characterized by layers of different brackish salinities support high densities of organisms ordered by the salinity gradient (Wilson \& Morris, 1994; Northup \& Lavoie, 2001; Seymour et al., 2007).
Sampling and analysis of the bacterial populations along the cave (Fig. 1), starting from the artificial entrance to the innermost part of the pools, allowed the assessment of the bacterial distribution. We analyzed by culture-dependent methods the diversity of bacterial species present in this habitat and we tested the ability of the isolated strains to form carbonate precipitates, and their mineralogical characteristics. Bacterial strains were isolated on R2A medium designed for oligotrophic bacteria and were identified by whole-cell protein profiles obtained by MALDI-TOF mass spectrometry and by molecular phylogenetic analysis of the 16S rRNA gene sequences.

A secondary purpose of the study was the description of the bacterial communities associated with the ferromanganese deposits (FMD) present in several parts of the cave showing uncommon mineral assemblages (Merino et al., 2009; Onac et al., 2014). These colorful deposits are likely related with ancient hypogenic episodes that have taken place during the cave speleogenesis (Fornós et al., 2011), and geochemical and microbiological studies suggest a biogenic origin as a result of redox reactions (Northup et al., 2001, 2003).

\section{Study site: cave location and description}

The Cova des Pas de Vallgornera lies in the Llucmajor municipality (located in southern Mallorca - Fig. 1) in the area known as "es Pas", less than $500 \mathrm{~m}$ from the coastline, on a structural carbonate platform

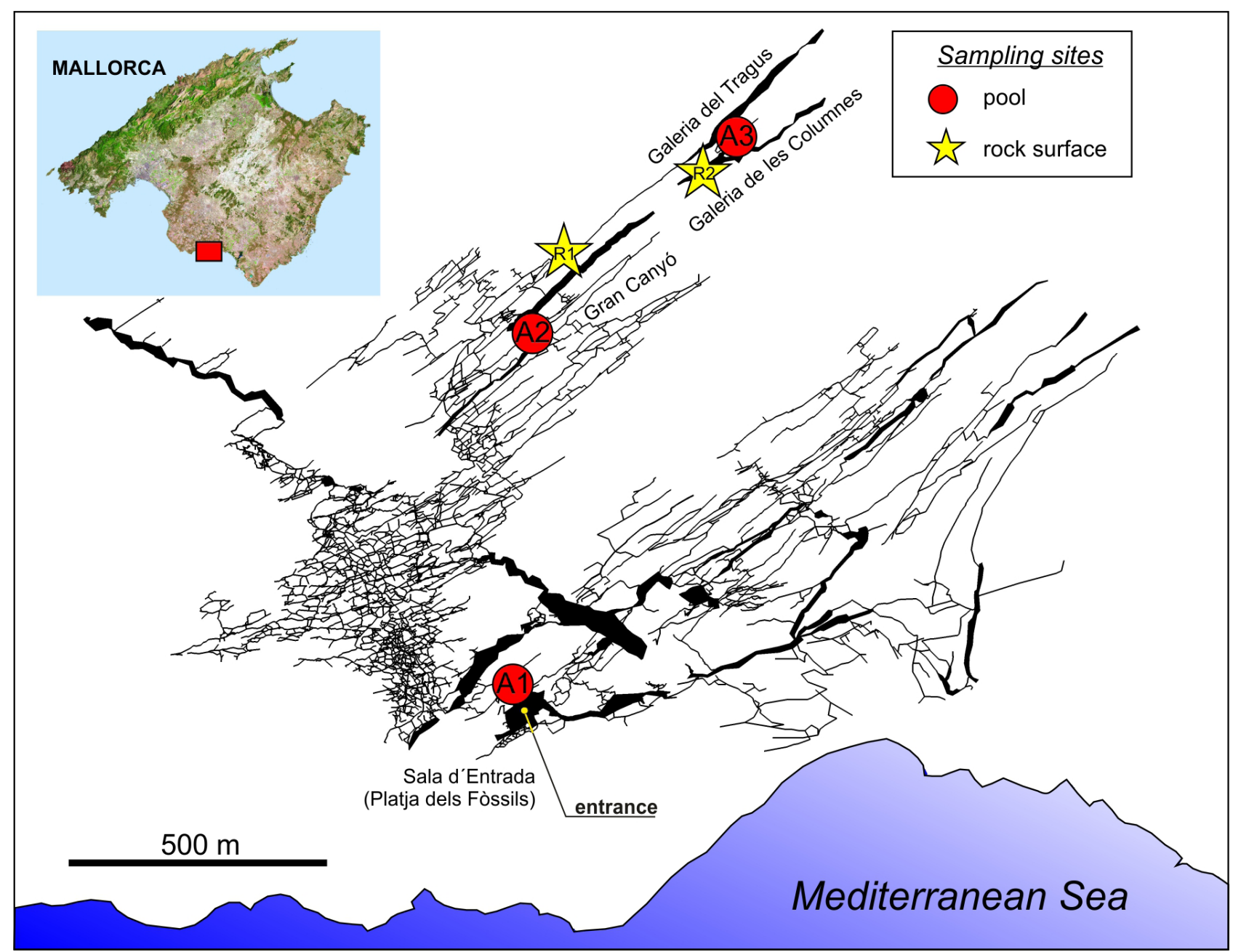

Fig. 1. Plan view of Cova des Pas de Vallgornera with the location of sampling points (survey map by Federació Balear d’Espeleologia). 
(coordinates UTM/WGS84, 489.120; 4.357.510). It corresponds to a littoral karstic region in a tabular platform built up by a Tortonian-Messinian reefal limestones sequence (Pomar, 1991) forming the best featured coastal karst area of the island, called Migjorn. The materials where the cave is developed show wide textural variability as a function of the reef architecture (Pomar et al., 1996; Fornós et al., 2002). Currently its surveyed length is over $74,000 \mathrm{~m}$, including more than $17,000 \mathrm{~m}$ of underwater extensions (Merino et al., 2011a, 2011b, 2014a, 2014b).

The cave corresponds to a subterranean complex formed by a series of breakdown chambers which are interconnected with each other by a network of passages roughly situated at two different elevations, lying around 7 to $11 \mathrm{~m}$ above the present mean sea level, and close to the current water table level to underwater, and with a plan development more or less parallel among them (Merino et al., 2014a). Part of the cave shows a labyrinthine pattern, but a series of rectilinear main passages that are structurally controlled are clearly recognizable, running relatively parallel from SW to NE. The distribution of linear passages, breakdown chambers, and maze galleries is associated with the characteristic rock textures related with the reefal Miocene sub-enviroments (Ginés et al., 2009a; 2014).

The cave shows a wide variety of speleothems, the presence of deposits with uncommon mineralogies, as well as outstanding and unique solutional features which evidence a very complex speleogenetic setting (Ginés et al., 2009b; 2014). Several speleogenetic processes are involved in their sculpturing. Apart from the classical karst processes with a noticeable meteoric water recharge, the morphological frame of the cave illustrates the typical coastal karstification and a possible deep recharge of hypogenic character. Features consisting of upwards solutional channels are abundant, including a complete morphologic suite of rising flow supporting the involvement of hypogene speleogenetic processes (Ginés et al., 2009b; Merino et al., 2009; Fornós et al., 2011). Both processes take place in a coastal karst setting (Lace \& Mylroie, 2013) where the mixing of marine and fresh waters leads to the presence of brackish water pools (Fig. 2), whose surfaces rise or fall with tidal (barometric) fluctuations of sea level. In this sense, the littoral mixing dissolution processes represent the most important speleogenetic mechanism to be considered in this eogenetic karst environment. The presence of copious cave rims and crusts developed along the floor, where vent features are clearly visible, shed light on the variety of minerals developed on these particular morphologies, apart from the ubiquitous carbonate minerals and the unexpected non carbonate minerals also identified (Merino et al., 2009; Onac et al., 2014).

\section{MATERIALS AND METHODS}

\section{Sampling}

The sampling strategy was as follows: samples were collected from the water table starting near the artificial entrance up to the inner and less accessible part of the cave, trying to avoid external contaminations, and on the multicolored FMD related with the presence of hypogenic features.

In November 2011 a total of 3 water samples (Table 1) were obtained aseptically into a sterile tube at $0.2 \mathrm{~m}$ depth in 3 different brackish pools located more or less in an equidistant position from the entrance of the cave (Platja dels Fòssils) to the farthest area (between Galeria del Tragus and Galeria de les Columnes) in a north-east direction (Figs. 1 and 2). Water samples were labeled A1, A2, and A3. Two samples of the multicolored Fe$\mathrm{Mn}$ rich deposits were also aseptically sampled by scraping the precipitate with a sterile scalpel into a sterile tube. Rock samples were labeled R1 and R2 (Table 1). Both types of samples were duplicated. The samples of water and surface crust multicolored deposits (Fig. 3) were collected aseptically in sterile tubes and kept at $4^{\circ} \mathrm{C}$, until microbiological analysis in less than 24 hours. The locations of the sampling sites are shown in Fig. 1.

\section{Physical and chemical parameters of the water}

Temperature, conductivity, $\mathrm{pH}$, redox and dissolved oxygen saturation of the water in the ponds were determined at monthly intervals using a recently calibrated Hanna Instruments 9828 Multiparameter Meter that was slowly lowered through the water. Total organic carbon (TOC) was measured as described by Barrón \& Durate (2009) with a TOC analyzer (Shimadzu TOC-5000A) in water samples taken at sampling point $A 1$, assumed to be representative of the water body.

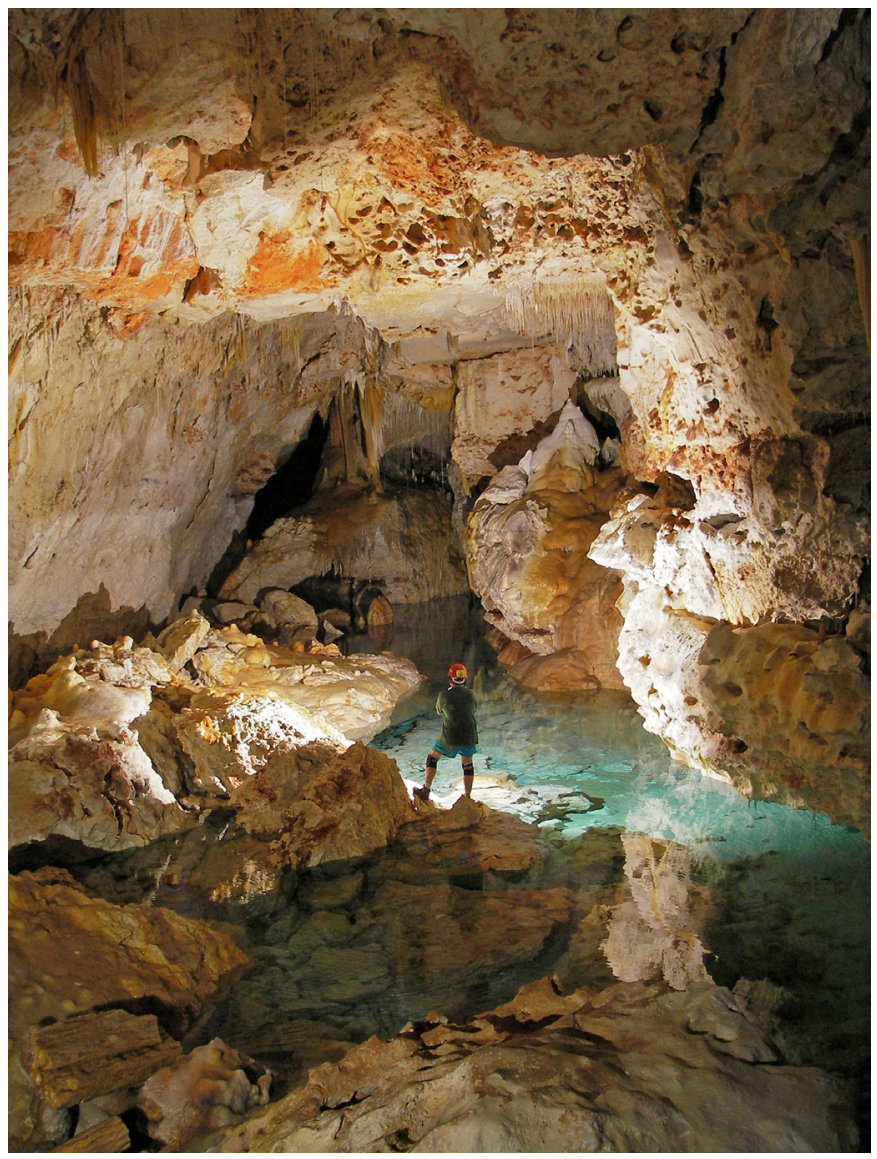

Fig. 2. Gran Canyó passage where some of the water samples were collected (A2). The brackish water table clearly covers part of the gallery (Photo: Antoni Merino). 
Table 1. Sampling sites location (Fig. 1) and characteristics.

\begin{tabular}{|c|c|c|c|c|}
\hline Sample & Location within the cave & Type & Location/depth & $\begin{array}{c}\text { Distance } \\
\text { from artificial } \\
\text { entrance }\end{array}$ \\
\hline A1 & Platja dels Fòssils & water & $\begin{array}{c}\text { Pool surface } \\
(-20 \mathrm{~cm})\end{array}$ & $83 \mathrm{~m}$ \\
\hline A2 & Gran Canyó & water & $\begin{array}{c}\text { Pool surface } \\
(-20 \mathrm{~cm})(\text { Fig. } 2)\end{array}$ & $875 \mathrm{~m}$ \\
\hline A3 & $\begin{array}{c}\text { Bragus and Galeria de les } \\
\text { Columnes }\end{array}$ & water & $\begin{array}{c}\text { Pool surface } \\
(-20 \mathrm{~cm})\end{array}$ & $1500 \mathrm{~m}$ \\
\hline R2 & $\begin{array}{c}\text { Tragus survey station } \\
840-841\end{array}$ & $\begin{array}{c}\text { Multicolored } \\
\text { deposits }\end{array}$ & $\begin{array}{c}\text { Rock wall } \\
(\text { roof surface } \\
\text { above vent) }\end{array}$ & $1083 \mathrm{~m}$ \\
\hline Galeria de les Columnes & $\begin{array}{c}\text { Multicolored } \\
\text { deposits }\end{array}$ & $\begin{array}{c}\text { Rock surface } \\
\text { (Fig. 3) }\end{array}$ & $1333 \mathrm{~m}$ \\
\hline
\end{tabular}

\section{Analysis of microbial communities by DAPI and FISH}

Fifty $\mathrm{ml}$ from each water sample (A1, A2, and A3) was filtered through $0.22 \mu \mathrm{m}$ polycarbonate filters (GTTP Millipore); the cells were fixed with paraformaldehyde solution (1\%) and washed twice with phosphate buffered saline. Samples of the multicolored deposits were resuspended in $15 \mathrm{ml}$ of Ringer and processed in the same way as the water sample. Total number of microorganisms was determined by DAPI staining (4', 6-diamidino-2phenylindole) (Porter \& Feig, 1980). Fluorescence insitu hybridizations (FISH) were performed using the probes EUB338 I-III (Amann et al., 1990, Daims et al., 1999) for the domain bacteria and Gam42a with competitor (Manz et al., 1992) for the analysis of total bacteria and Gammaproteobacteria, the predominant class in the samples. Probes were synthesized with Cy3 fluorocrome at 5'-end (Thermo Scientific). Filters were observed on a Zeiss epifluorescence microscope (Axiophot) with the corresponding filters.

\section{Culturable bacteria cell counts and strains isolation}

Water samples $(100$ and $200 \mu 1)$ were inoculated on R2A agar, a medium designed for the culture of oligotrophic bacteria (Reasoner \& Geldreich, 1985) and on a selective medium, CFC medium. CFC medium consisted on Pseudomonas agar F (Difco) containing cephaloridine $\left(50 \mathrm{mg}^{-1}\right)$, fucidin $\left(10 \mathrm{mg} \mathrm{l}^{-1}\right)$ and cetrimide $\left(10 \mathrm{mg}^{-1}\right)$ selective for Pseudomonas because this was the predominant genus detected in previous analysis. Plates were incubated at $18^{\circ} \mathrm{C}$ for two weeks. The multicolored deposit samples were

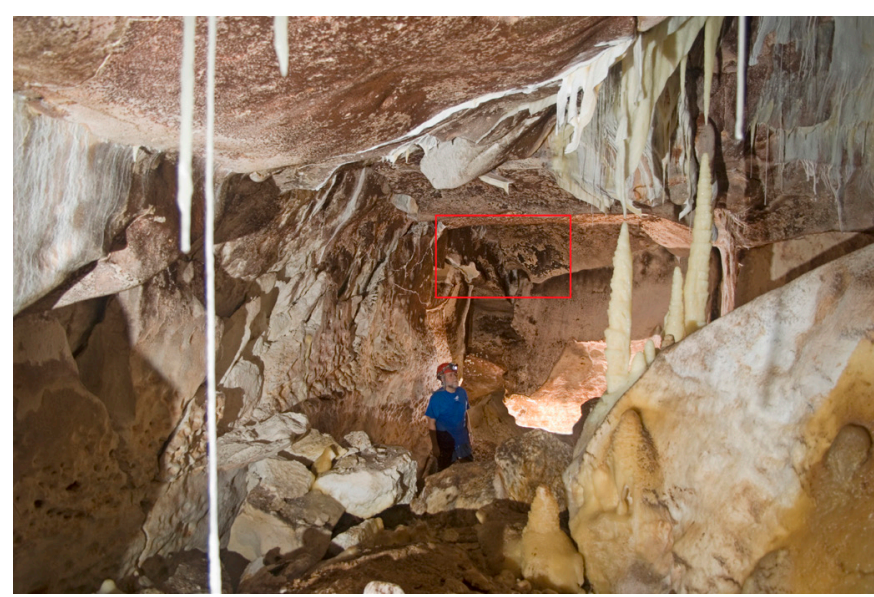

Fig. 3. Sampled dark brown multicolored deposits (R2) covering the wall and ceiling (square) of Galeria de les Columnes (Photo: Antoni Merino). suspended in Ringer (1.7 $\mathrm{g}$ in $15 \mathrm{ml}$ final volume) and 100 and $200 \mu \mathrm{l}$ of the multicolored deposits suspension were inoculated onto R2A and CFC medium and incubated in the same conditions. All the clearly separated colonies observed were subcultured and purified by repeated streaking on R2A or CFC mediums and stored in glycerol at $-70^{\circ} \mathrm{C}$.

\section{Whole cell matrix-assisted linear desorption/ ionization-time-of-flight mass spectrometry (WC-MALDI-TOF MS)}

WC-MALDI-TOF MS is a precise and rapid method used in microbial ecology for the analysis of a large set of colonies. The principle is the total cell protein profiling of the colonies and the groupings of the profiles in clusters of colonies of the same species. Details are given in Welker \& Moore (2011). A small amount (5-10 mg) of material was taken from freshly grown colonies and transferred with a loop into a $1.5 \mathrm{ml}$ Eppendorf tube. Three-hundred microliters of MilliQ sterilized water were added, mixed by pipetting and subsequently $900 \mu \mathrm{l}$ of absolute ethanol was added and mixed. The Eppendorf tubes were centrifuged at $16,000 \mathrm{x} g$ for $2 \mathrm{~min}$ and the supernatant removed. After this, $50 \mu \mathrm{l}$ of formic acid (70\%) was added and mixed by pipetting. Acetonitrile $(50 \mu \mathrm{l})$ was added and mixed. The tubes were centrifuged at $16,000 \mathrm{x} g$ for $2 \mathrm{~min}$ and the supernatant transferred to another tube. One microliter of the supernatant was placed on to a spot of a ground steel plate and air dried at room temperature. Each sample was overlaid with 1 $\mu \mathrm{l}$ of matrix solution (saturated solution of a-cyno4-hydroxy-cinnamic acid in 50\% acetonitrile-2.5\% trifluoroacetic acid) and air dried at room temperature.

Spectra were obtained on an Autoflex III MALDI-TOF / TOF mass spectrometer (Bruker Daltonics, Leipzig, Germany) equipped with a 200-Hz Smartbeam laser. Spectra were recorded in the linear, positive mode at a laser frequency of $200 \mathrm{~Hz}$ within a mass range from 2,000 to $20,000 \mathrm{Da}$. The IS1 voltage was $20 \mathrm{kV}$, the IS2 voltage was maintained at $18.7 \mathrm{kV}$, the lens voltage was $6.50 \mathrm{kV}$, and the extraction delay time was 120 ns. Approximately 500 shots from different positions of the target spot were collected and analyzed for each spectrum. The spectra were calibrated externally using the Bruker Bacterial Test Standard (Escherichia coli extract including the additional proteins RNase A and myoglobin). Calibration masses were as follows: RL29 3637.8 Da; RS32, 5096.8 Da; RS34, 5381.4 Da; RL33meth, 6255.4 Da; RL29, 7274.5 Da; RS19, 10300.1 Da; RNase A, 13683.2 Da; myoglobin, 16952.3 Da).

The different spectra obtained for each isolate under study were analyzed with the Biotyper vs 1.0 software for presumptive identification and to determine the similarities among the spectra. A dendrogram was generated for clustering the strains with high similarity. Between 2 and 9 representatives of each cluster were selected for further molecular analysis.

Microbial identification and phylogenetic analysis

Representative strains of each WC-MALDI-TOF MS group (100 strains in total) were selected and their 
16S rRNA gene partially sequenced and analyzed. Total DNA from a $5 \mathrm{ml}$ liquid R2A culture was extracted by lysis with sodium dodecyl sulphate (SDS)-proteinase $\mathrm{K}$, and treatment with CTAB (cetyltrimethylammonium bromide) (Wilson, 1987). The 16S rRNA genes were amplified using the 16S rRNA primers 16f27 (5'-AGAGTTTGATCMTGGCTCAG-3') and 16r1492 (5'-TACGGYTACCTTGTTACGACTT-3') (Lane, 1991). For the 18S rRNA amplification of eukaryotic cells the primers used were EukA (5'-AACCTGGTTGATCCTGCCAGT-3') and EukB (5'-TGATCCTTCTGCAGGTTCACCTAC-3') (Medlin et al. 1988). The same PCR conditions were used as described in Gomila et al. (2005). Five microliters of amplified PCR products was analyzed by electrophoresis on $1 \%$ agarose gels and stained with ethidium bromide. The gene amplicons were purified using MultiScreen Filter Plates (Millipore) and sequenced directly using the ABI PRISM BigDye Terminator Cycle sequencing kit according to the manufacturer's instructions. The primers used for sequencing in one direction were $16 \mathrm{f} 27$ and EukA. Sequences were read with an automatic sequence analyzer (ABI PRISM 377 DNA sequencer, PE Biosystems). Partial 16S rRNA and 18S rRNA sequences (mean nucleotide length 780 nucleotides; minimum 500 nucleotides) were aligned to the closest relatives reference sequences of type strains in the EzTaxon nucleotide sequence database (www.eztaxon.org) and NCBI nucleotide sequence database for 18S rRNA. For identification, the sequences were also aligned by a hierarchical method for multiple alignments implemented in the CLUSTAL $X$ computer program (Thompson et al., 1997). Automatically aligned sequences were checked manually. Evolutionary distances derived from sequence pair dissimilarities (Jukes-Cantor correction [Jukes \& Cantor, 1969]) was calculated with the DNADIST program included in the Phylogenetic Inference Package (PHYLIP version 3.5c) (Felsenstein, 1989). Phylogenetic trees were constructed by the neighbor-joining distance method. Bootstrap analysis (1,000 replicates) was done with the PHYLIP package. Bootstrap values higher than 500 are indicated as percentage in the corresponding branching points of the trees (Supplementary Figs. S1 \& $\underline{\text { S2 }}$ - Supplementary Figures and Tables can be found here: http://dx.doi. org/10.5038/1827-806X.43.2.8). Topologies of the trees were visualized with the TreeView program (Page, 1996). A bacterial strain was assigned to a known species when the sequence similarity to the closest type strain was higher than $97 \%$ and was located in the same phylogenetic branch in the tree. Abortipus and Aspergillus strains were assigned to the closest type strain. Nucleotide sequences were deposited at the NCBI and accession numbers are indicated in Supplementary Table S1.

\section{Diversity indices}

Diversity indices and rarefaction curves for statistical estimation of the bacterial diversity were calculated using the PAST software vs. 2.17. Shannon index was correlated with richness and relative species abundance. Abundance and dominance are indicated by the evenness index and by the Simpson's index. Coverage index $(C)$ was calculated as $C=1-(n / N), n$ being the number of species appearing only once and $\mathrm{N}$ being the total number of colonies analyzed. The $\mathrm{S}_{\text {Chao1 }}$ estimator (Kemp \& Aller, 2004), as an estimate of the total number of species present, is calculated as $\mathrm{S}_{\text {Chao1 }}=\mathrm{S}_{\mathrm{obs}}+\mathrm{F}_{1}{ }^{2} / 2\left(\mathrm{~F}_{2}+1\right)-\mathrm{F}_{1} \mathrm{~F}_{2} / 2\left(\mathrm{~F}_{2}+1\right)^{2}$, where $\mathrm{S}_{\text {obs }}$ is the number of species observed in the bacterial strains collection, and $F_{1}$ and $F_{2}$ are the number of species occurring either one or two times. The same estimation was calculated for the genera detected.

\section{Calcite precipitation by bacteria}

To assess their possible influence on calcite precipitation or dissolution, all bacterial isolates (229) were cultured on 3 different media: B-4 agar (Boquet et al., 1973), B-4C agar (B-4 agar with an overlay of $1.5 \%$ agar with $2 \%$ calcium carbonate light powder (Panreac) as described by Banks et al. (2010) and R2AC agar (R2A agar with an overlay of $1.5 \%$ agar with $2 \%$ calcium carbonate light powder - Panreac). The plates were incubated aerobically at $18^{\circ} \mathrm{C}$. Petri dishes were examined periodically by light microscopy for up to 25 days for the presence of crystals or clearing zone around the colonies. Controls consisted of non-inoculated culture medium incubated under the same conditions. Crystals from the positive plates were purified for further analysis as follows: all the agar of the Petri dish, $20 \mathrm{ml}$ approximately, was transferred to a $50 \mathrm{ml}$ Falcon tube and $30 \mathrm{ml}$ of MilliQ sterile water was added. The sample was heated in a microwave oven until the agar was molten, and the crystals settled to the bottom of the tube without the need for centrifugation. The supernatant was removed and the sediment was air dried.

\section{X-ray diffraction analysis and SEM observation}

Crystals were observed under a binocular microscope before X-ray diffraction study. Their mineralogy was determined with a Siemens D-5000 X-ray diffractometer, with secondary graphite monochromator, fixed slit, CuKa radiation and on-line connection with a microcomputer. Data were collected for 5 seconds integration time in $0.052 \theta$ steps at $40 \mathrm{kV}$ and $30 \mathrm{~mA}$ in a $2 \theta$ interval between 3 and $60^{\circ} \mathrm{C}$, using randomly oriented powders of the bulk sample. No pretreatment was made on them. Data processing was performed using EVA ver. 7.0 software program in order to obtain the mineral composition. When more than one phase was present, a semi-quantitative mineral analysis composition was obtained based on the peak areas. All samples were observed and photographed by scanning electron microscopy (Hitachi S-3400N Type II SEM microscope). Selected samples were analyzed by Energy-dispersive X-ray spectroscopy attached to SEM (EDX, Bruker X-Flash Detector 4020).

\section{RESULTS}

\section{Physical and chemical parameters of the brackish water}

Several physical and chemical parameters of the water at sampling point $A 1$, as representative of the 
whole water body, were determined from December 2011 until March 2013 at three hours interval. The average values were: temperature $19.5( \pm 0.1){ }^{\circ} \mathrm{C}$, conductivity $10.26( \pm 1.1) \mu \mathrm{S} / \mathrm{cm}$ (equivalent to $0.6 \%$

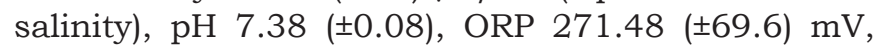
dissolved oxygen $101.2( \pm 7.4) \%$. Total organic carbon (TOC) ranged from 0.69 to $0.92 \mathrm{mg} / 1$ (mean value $0.81 \mathrm{mg} / 1)$ characteristic of oligotrophic waters.

\section{DAPI and FISH bacterial cell counts}

Total cell counts by DAPI of the 3 water samples (A1, $\mathrm{A} 2$, and $\mathrm{A} 3$ ) ranged from $1.2 \times 10^{5}$ to $4.5 \times 10^{4}$ (Table 2). The results obtained for the FISH probes, EUB338 and GAMMA, showed that $15 \%$ of the total cell count can be considered as active Gammaproteobacteria and $31 \%$ as active bacteria in sample A1. In sample A2, $11 \%$ of the bacteria counted by DAPI stain can be considered as active gammaproteobacteria. FISH counts in sample A3 was below the detection limit of the method. Bacteria in the samples of the multicolored precipitate were detected associated with mineral particles and the EUB probe indicated that only $3.3 \%$ were active and none was detected with the gammaproteobacteria probe.

\section{Culturable bacterial cell counts}

Cell counts on plates of R2A medium for oligotrophic bacteria and CFC medium for Pseudomonas varied among the samples. Culturable bacteria in the cave entrance reached the highest value (sample A1) and decreased in sample A2 (5.5\% of A1) and A3 (1\% of A1). Cell counts obtained in CFC medium were lower, on the order of $6 \%$ in $\mathrm{A} 1$ and $0.5 \%$ in $\mathrm{A} 2$ of the values obtained in R2A medium and no colonies were detected in sample A3. In the multicolored deposit sample R1, 1,120 cfu/ $\mathrm{ml}$ was detected, approximately 10 times the culturable bacteria detected in R2, which was $1-10 \%$ of the total cell count. In sample R1 two different colony morphologies were detected and only one in R2. In all samples, the FISH counts were $1-10 \%$ of the DAPI counts.

\section{Whole cell MALDI-TOF mass spectrometry}

Most of the isolates obtained in R2A medium (214 strains) and in CFC medium (34 strains) from the water and rock samples were analyzed by WCMALDI-TOF MS. In total 248 isolates were analyzed, 263 colonies from A1, 50 from A2 and 10 from A3. The isolates of the multicolored deposits samples (R1 and R2) presented only two different colony morphologies in R2A agar and 25 isolates of both morphologies were selected for identification. As

Table 2. Viable cell counts on R2A and CFC media, total count by DAPI, and FISH cell counts for Bacteria (EUB) and Gammaproteobacteria (GAMMA).

\begin{tabular}{|c|c|c|c|c|c|}
\hline Sample & R2A (CFU/ml) & CFC (CFU/ml) & $\begin{array}{c}\text { DAPI } \\
\text { (cells/ml) }\end{array}$ & $\begin{array}{c}\text { EUB } \\
\text { (cells/ml) }\end{array}$ & $\begin{array}{c}\text { Gamma } \\
\text { (cells/ml) }\end{array}$ \\
\hline A1 & $1.76 \times 10^{3}$ & $1.07 \times 10^{2}$ & $1.7 \times 10^{5}$ & $5.3 \times 10^{4}$ & $2.7 \times 10^{4}$ \\
\hline A2 & $9.7 \times 10^{1}$ & 3.33 & $1.0 \times 10^{5}$ & $1.1 \times 10^{4}$ & $1.1 \times 10^{4}$ \\
\hline A3 & $1.8 \times 10^{1}$ & n.d. & $4.5 \times 10^{4}$ & n.d. & n.d. \\
\hline R1 & $1.12 \times 10^{3}$ & n.d. & $1.3 \times 10^{4}$ & $4.4 \times 10^{2}$ & n.d. \\
\hline R2 & $1.60 \times 10^{2}$ & n.d. & $1.4 \times 10^{4}$ & $4.4 \times 10^{2}$ & n.d. \\
\hline
\end{tabular}

n.d.: not detected indicated in Supplementary Fig. S1 the clustering of the MALDI-TOF mass spectra based on a maximal 700 distance of 1,000 , allowed the differentiation of 16 clusters of 3 or more strains, A to P. More than $50 \%$ of the strains clustered in 5 groups: group B with 32 strains, group $\mathrm{C}$ with 11 strains, group I with 55 strains, group $\mathrm{O}$ with 23 strains and group $\mathrm{P}$ with 16 strains. The groups A, F, G, H, I, J, M, $\mathrm{N}$, and $\mathrm{P}$ included exclusively isolates of the cave entrance sample (A1) and the group $\mathrm{K}$ isolates of the intermediate sample (A2). Group C strains were isolated from the multicolored deposits samples (R). The groups $\mathrm{B}, \mathrm{D}$, and $\mathrm{L}$ contained isolates from the samples $A 1$ and $A 2$, and the group $O$ is composed by isolates from the samples A1, A2, A3 and R. As visible in Supplementary Fig. S1 the Biotyper database allowed only the identification with confidence (values higher than 1.5 in the program) of 101 strains, 98 strains at the species, and 3 strains at the genus level.

\section{Strain identification by partial rRNA analysis}

A total of 100 representative strains, from 2 to 10 from each of the 16 MALDI-TOF clusters, comprising all the isolates that produced mineral precipitates (as explained later) were further analyzed by $16 \mathrm{~S}$ rRNA gene sequence analysis. At least the first 700 nucleotides of the $16 \mathrm{~S}$ rRNA gene were analyzed for the 100 isolates selected, with only 5 exceptions in which the length was shorter. Results are indicated in Supplementary Table S1 and Supplementary

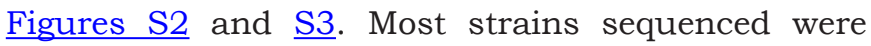
Proteobacteria $(72 \%)$ and Actinobacteria (19\%). The predominant genera of the sample A1 were Acinetobacter and Pseudomonas, both members of the Gammaproteobacteria class. The most abundant genera in sample A2 were Pseudomonas, Micrococcus, and Moraxella. Sample A3 was dominated by Psychrobacter and Pseudomonas. The genera detected in sample R1 were Nocardiodes and Pseudomonas, whereas only Nocardiodes (Supplementary Fig. S3) was found in sample R2. Two genera of fungi were also identified by sequencing the 18S rRNA: Aspergillus and Abortiporus in samples A1 and A3.

\section{Combined identification}

Ninety-three percent of the isolates of the water samples were assigned to a known species or genus by combining the WC MALDI TOF groupings and the phylogenetic analysis of the representative strains. Thirty-four strains were only identified at the species level. Both methods assigned a strain to the same genus and species in most cases, but discrepancies were observed in 29 strains (the same phylogenetic species assignation of 2 strains but located in 2 MALDI-TOF groups, or 2 strains in the same MALDI-TOF group with different phylogenetic species assignation). The phylogenetic identification was considered as more reliable when discrepancies were observed. Table 3 indicates the species or genera identified in the 3 water samples. Strains isolated from samples R1 and R2 (multicolored precipitates) were ascribed to Nocardioides luteus and Pseudomonas benzenivorans. Sequences were deposited at the 
Table 3. Identification of the strains isolated from the water samples in R2A agar.

Sample A1

\begin{tabular}{|c|c|c|c|c|}
\hline Genus assignation & $\begin{array}{c}\text { Number } \\
\text { of } \\
\text { strains }\end{array}$ & Species assignation & $\begin{array}{c}\text { Number } \\
\text { of } \\
\text { strains }\end{array}$ & $\begin{array}{c}\text { Similarity } \\
\text { to the } \\
\text { type } \\
\text { strain }\end{array}$ \\
\hline \multirow[t]{9}{*}{ Acinetobacter } & 75 & Acinetobacter Iwoffii & 5 & 100 \\
\hline & & Acinetobacter schindleri & 51 & $99.1-99.7$ \\
\hline & & Acinetobacter gyllenbergii & 2 & $99.2-99.6$ \\
\hline & & Acinetobacter haemolyticus & 1 & 99.7 \\
\hline & & Acinetobacter guillouiae & 6 & $96.5-98.9$ \\
\hline & & Acinetobacter sp. A & 4 & \\
\hline & & Acinetobacter sp. B & 1 & \\
\hline & & Acinetobacter sp. C & 3 & \\
\hline & & Acinetobacter sp. D & 2 & \\
\hline \multirow[t]{8}{*}{ Pseudomonas } & 21 & Pseudomonas stutzeri & 1 & $99.5-99.9$ \\
\hline & & Pseudomonas xanthomarina & 12 & 98.8-99.4 \\
\hline & & Pseudomonas alcaligenes & 1 & 98.9 \\
\hline & & Pseudomonas psychrotolerans & 1 & 99.2 \\
\hline & & Pseudomonas reinekei & 2 & 100 \\
\hline & & Pseudomonas brenneri & 2 & 99.7 \\
\hline & & Pseudomonas extremaustralis & 1 & 99.3 \\
\hline & & Pseudomonas rhodesiae & 1 & 99.3 \\
\hline Massilia & 8 & Massilia timonae & 8 & $96.5-99.4$ \\
\hline \multirow[t]{2}{*}{ Shigella } & 6 & Shigella flexneri & 6 & 100 \\
\hline & & Shigella boydii & 1 & 99.1 \\
\hline Rheinheimera & 2 & Rheinheimera soli & 2 & $98.1-99.1$ \\
\hline Sphingobium & 2 & Sphingobium rhizovicinum & 2 & 99 \\
\hline \multirow[t]{2}{*}{ Brevundimonas } & 2 & Brevundimonas diminuta & 1 & 99.8 \\
\hline & & Brevundimonas vesicularis & 1 & 99.5 \\
\hline Abortiporus & 1 & Abortiporus biennis & 1 & 87.2 \\
\hline Micrococcus & 1 & Micrococcus yunnanensis & 1 & 100 \\
\hline Stenotrophomonas & 1 & Stenotrophomonas maltophilia & 1 & 98.8 \\
\hline Aeromonas & 1 & Aeromonas eucrenophila & 1 & \\
\hline Nocardioides & 1 & Nocardioides terrigena & 1 & 96.7 \\
\hline Sphingomonas & 1 & Sphingomonas desiccabilis & 1 & \\
\hline Microbacterium & 1 & $\begin{array}{l}\text { Microbacterium } \\
\text { esteraromaticum }\end{array}$ & 1 & 99.7 \\
\hline Moraxella & 1 & Moraxella sp. & 1 & \\
\hline Total Identified & 124 & & 93 & \\
\hline Total not identified & 8 & & 39 & \\
\hline number of genera & 15 & number of species & 26 & \\
\hline
\end{tabular}

EMBL database (http://www.ebi.ac.uk/ena/) under accession numbers HG738872-HG738971 and are given in Supplementary Table S1.

\section{Diversity indexes and rarefaction curves}

As indicated in Table 4, the number of genera and species detected on R2A in the water samples was: sample A1, 15 genera and 26 species (18 species were singletons); sample A2, 10 genera and 15 species (8 species were singletons); sample A3, 6 genera and 8 species ( 7 species were singletons).
Sample A2

\begin{tabular}{|c|c|c|c|c|}
\hline Genus assignation & $\begin{array}{l}\text { Number } \\
\text { of } \\
\text { strains }\end{array}$ & Species assignation & $\begin{array}{c}\text { Number } \\
\text { of } \\
\text { strains }\end{array}$ & $\begin{array}{l}\text { Similarity } \\
\text { to the } \\
\text { type } \\
\text { strain }\end{array}$ \\
\hline \multirow[t]{4}{*}{ Pseudomonas } & 20 & Pseudomonas moorei & 3 & 98.3 \\
\hline & & Pseudomonas monteilii & 15 & $99.4-99.6$ \\
\hline & & Pseudomonas borbori & 1 & 99.1 \\
\hline & & Pseudomonas benzenivorans & 1 & \\
\hline \multirow[t]{4}{*}{ Micrococcus } & 9 & Micrococcus yunnanensis & 2 & 99.8 \\
\hline & & Micrococcus terreus & 2 & 100 \\
\hline & & Micrococcus antarcticus & 4 & $99.4-99.6$ \\
\hline & & Micrococcus sp. & 1 & \\
\hline \multirow[t]{2}{*}{ Moraxella } & 5 & Moraxella osloensis & 4 & $99.7-99.8$ \\
\hline & & Moraxella sp. & 1 & \\
\hline Kocuria & 2 & Kocuria palustris & 2 & 100 \\
\hline Nocardioides & 2 & Nocardioides terrigena & 2 & 96.7 \\
\hline Sphingomonas & 2 & Sphingomonas desiccabilis & 2 & \\
\hline Staphylococcus & 1 & Staphylococcus pasteuri & 1 & 100 \\
\hline Brevundimonas & 1 & Brevundimonas vesicularis & 1 & 99.5 \\
\hline Kytococcus & 1 & Kytococcus sedentarius & 1 & \\
\hline Arhrobacter & 1 & Arhrobacter castelli & 1 & \\
\hline Total Identified & 44 & & 40 & \\
\hline Total not identified & 4 & & 8 & \\
\hline number of genera & 10 & number of species & 15 & \\
\hline
\end{tabular}

Sample A3

\begin{tabular}{|c|c|c|c|c|}
\hline Genus assignation & $\begin{array}{c}\text { Number } \\
\text { of } \\
\text { strains }\end{array}$ & Species assignation & $\begin{array}{c}\text { Number } \\
\text { of } \\
\text { strains }\end{array}$ & $\begin{array}{c}\text { Similarity } \\
\text { to the } \\
\text { type } \\
\text { strain }\end{array}$ \\
\hline \multirow[t]{2}{*}{ Psychrobacter } & 3 & Psychrobacter piscatorii & 1 & 99.4 \\
\hline & & Psychrobacter pacificensis & 2 & 99.6 \\
\hline \multirow[t]{2}{*}{ Pseudomonas } & 2 & Pseudomonas fuscovaginae & 1 & 98.5 \\
\hline & & Pseudomonas monteilii & 1 & 99.6 \\
\hline Aspergillus & 1 & Aspergillus oryzae & 1 & 87.9 \\
\hline Hydrogenophaga & 1 & Hydrogenophaga palleronii & 1 & 99.3 \\
\hline Microbacterium & 1 & $\begin{array}{c}\text { Microbacterium } \\
\text { paraoxydans }\end{array}$ & 1 & 99.8 \\
\hline Streptomyces & 1 & Streptomyces xantholiticus & 1 & 98.9 \\
\hline Total Identified & 9 & & 9 & \\
\hline Total not identified & 1 & & 1 & \\
\hline number of genera & 6 & number of species & 8 & \\
\hline
\end{tabular}

Due to the high number of singletons in the species analysis, the diversity indexes and rarefaction curves were only calculated for the genera detected. None of the rarefaction curves reached a saturation profile (Fig. 4) indicating that not all the diversity was detected. However, the coverage of genera was higher than $90 \%$ in samples A1 and A2. Table 3 also shows the indexes for bacteria isolated from the multicolored precipitate samples. Only 2 species were detected and the indexes demonstrate that species diversity was exhaustively analyzed. 
Table 4. Diversity indices of the genera detected at the 4 sampling sites in R2A medium.

\begin{tabular}{|l|c|c|c|c|c|}
\hline \multicolumn{1}{|c|}{ Genera Diversity } & All sites & A1 & $\begin{array}{c}\text { Samples } \\
\text { A2 }\end{array}$ & A3 & R1-R2 \\
\hline Taxa (S) & 23 & 15 & 10 & 6 & 2 \\
\hline Individuals & 178 & 124 & 44 & 9 & 25 \\
\hline Dominance (D) & 0.248 & 0.4023 & 0.2696 & 0.2099 & 0.5072 \\
\hline Shannon (H) & 1.978 & 1.439 & 1.696 & 1.677 & 0.6859 \\
\hline Simpson (1-D) & 0.752 & 0.5977 & 0.7304 & 0.7901 & 0.4928 \\
\hline Evenness (H/S) & 0.3144 & 0.2811 & 0.545 & 0.8916 & 0.9928 \\
\hline Coverage (C) & $94.90 \%$ & $93.50 \%$ & $90.90 \%$ & $55.60 \%$ & $100 \%$ \\
\hline S & 224.8 & 142.3 & 41.6 & 21.5 & 2.0 \\
\hline
\end{tabular}

\section{Mineral precipitates}

To assess whether microbial activity played a role in $\mathrm{CaCO}_{3}$ deposition and dissolution, all bacteria isolated were plated onto B-4, B-4C and R2AC agar, which allow the discrimination of those bacterial strains with the ability to either precipitate or dissolve $\mathrm{CaCO}_{3}$. Bacterial growth, crystal formation and crystal dissolution was checked at $18^{\circ} \mathrm{C}$ for 2-4 weeks. The strains able to precipitate $\mathrm{CaCO}_{3}$ are indicated in Supplementary Table S1. None of the analyzed isolates dissolved $\mathrm{CaCO}_{3}$. Forty-nine strains precipitated $\mathrm{CaCO}_{3}$ and were classified in 30 species: Acinetobacter (10 strains, 3 species), Pseudomonas (8 strains, 5 species), Nocardioides (4 strains, 2 species), Micrococcus (6 strains, 3 species), Psychrobacter (2 strains, 1 species), Shigella (2 strains, 2 species), Kocuria (2 strains, 1 species), Microbacterium (2 strains, 2 species), Sphingobium (2 strains, 1 species), Brevundimonas (2 strains, 2 species), Massilia (2 strains, 1 species) and Achromobacter, Hydrogenophaga, Moraxella, Stenotrophomonas, Streptomyces, Abortiporus, and Aspergillus (1 strain, 1 species each genus). Strains of the same species could differ in their capacity to precipitate crystals. In 9 species, strains were detected with the ability to form crystals and other strains in the same species were not. P. xanthomarina strain A1a-45 drew attention, because it was the only one of 25 strains isolated of this species that was able to precipitate $\mathrm{CaCO}_{3}$ crystals.

Crystalline materials first detected by light microscopy were later observed by SEM and analyzed

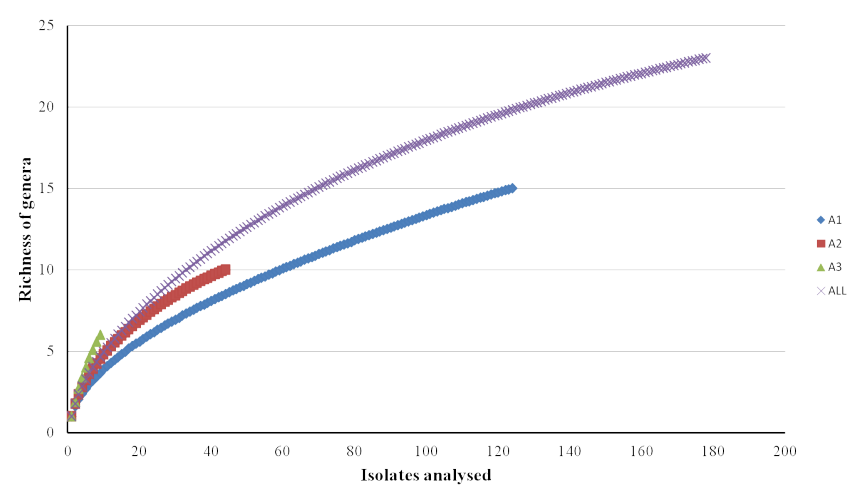

Fig. 4. Rarefaction curves of the diversity of genera detected in on R2A medium in the 3 water samples $(A 1, A 2$, and $A 3)$ and in all 3 samples. by X-ray diffraction. These observations were made in all the cases where mineral precipitates were present. In some of the samples the main phase present was calcite and verified by the EDX analysis that corroborated the presence of $\mathrm{Ca}, \mathrm{C}$, and $\mathrm{O}$ in atomic percent ratios related to $\mathrm{CaCO}_{3}$.

In the case of calcite, variability in crystal growth and characteristics of external shape could be observed. The SEM results (Fig. 5) demonstrated the presence of calcium carbonate mineral polymorphs. The mineral precipitates show both spherical and rhombohedral morphological growth forms. Some of the aggregates resemble a cubic morphology. Larger scale morphologies are very variable showing twining and intergrown crystalline aggregates. The anhedral spherical or globular forms (sometimes with a twin growth shape) dominated in most of the samples over the rhombohedra appearance. Those spherical aggregates are clearly made of rhombohedra crystals. The rhombohedral crystals show an idiomorphic tendency with the crystal size. The precipitates showed a white color or are slightly whitish to colorless. The mean grain size of calcite precipitates ranged between 50 and $70 \mu \mathrm{m}$ in most of the samples, although some crystals are greater than $120 \mu \mathrm{m}$.

Apart from the differences in the external crystal shape and growth, some variations in mineralogy were observed. Struvite was only present in two samples. It showed a set of crystal aggregates ranging between 1 and $2 \mathrm{~mm}$ (Fig. 6) consisting of more or less idiomorphic pyramidal and bladed crystals (around $250 \mu \mathrm{m}$ in length). This phase was present exclusively related with the fungal species Aspergillus oryzae. In the case of $P$. xanthomarina strain A1a-45 either calcite or struvite were observed.

In the case of isolates related with the FMD deposits (R1 and R2), only one species (Nocardioides luteus) produced calcite precipitates. These crystals mostly showed a rhombohedral shape although some globular forms were also present (Fig. 6).

\section{DISCUSSION AND CONCLUSIONS}

The waters in Cova des Pas de Vallgornera originate from vertical infiltration from surface rainfall and the mixing with marine waters due to lateral infiltrations, resulting in brackish highly oligotrophic waters, which represent a singular habitat for microbial communities. To our knowledge, this is the first report of bacterial communities in cave anchialine waters of the Balearic Islands. It is a very stable habitat, with almost constant temperature all year and with low levels of organic matter. No photosynthetic activity has been detected in the cave and the contribution of organic matter by metazoan organisms is very limited (Gràcia et al., 2009). Bacteria that have adapted their metabolic properties to this environment are only present in low numbers and are represented mainly by Gamma- and Betaproteobacteria, as well as Actinobacteria. Total cell counts diminished from the entrance of the cave to the most distal part. These results correlate with the distance to the sea water and with the frequency of visitors in the 3 parts of the 


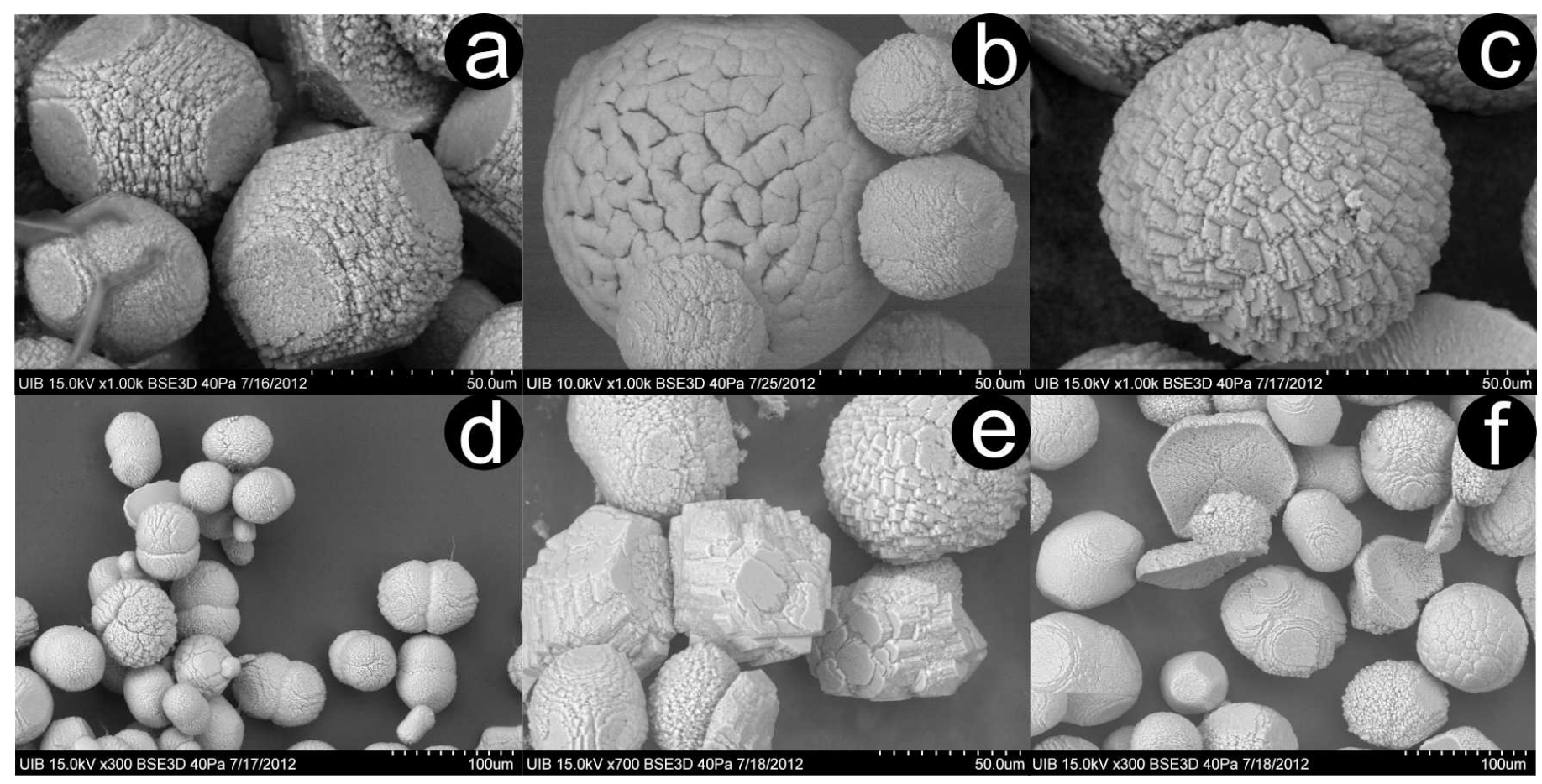

Fig. 5. SEM images of calcite precipitates showing differences in crystal morphology related with the bacterial species recovered in the water pools: a) Achromobacter spanius; b) Pseudomonas xanthomarina; c) Sphingobium rhizovicinum; d) Brevudimonas diminuta; e) Acinetobacter schindleri; f) Micrococcus terreus.

cave studied. Visits are only allowed for exploration, survey, and research purposes. In the proximity of the entrance, only 200 visitors are allowed each year, and the number decreases drastically towards the central part of the cave, whereas less than a few tens of visitors reach the distal parts. The detection in A1 of enterobacterial colonies (Shigella) can be related to levels of human exposure but the highest numbers of culturable bacteria detected at the entrance, and the different composition of the bacterial communities in each sampling point, can be explained by the infiltration of sea water providing nutrients for bacterial growth. The Gammaproteobacteria are present in all 3 samples, but were most abundant in the entrance. The Actinobacteria were most abundant in the distal part of the cave. The species or genera richness decreased with increasing distance to the entrance of the cave, the most visited part. With the culture methods used, only 2 species of fungi (Aspergillus sp. and Abortiporus sp.) were detected from sample A1.

The diversity of bacterial species was not exhaustively studied in the water samples, but the coverage index of the genera detected reached $95 \%$ of the estimated genera diversity and Acinetobacter and Pseudomonas species dominated over the other species. Both genera are considered ubiquitous and metabolically versatile. The relevance of Pseudomonas populations was emphasized in recent culture independent analysis in karst aquifers (Gray et al., 2013).

Biologically induced mineralization of calcium carbonate can take place passively (metabolically driven changes in the chemistry around the living organisms) or actively (when the organism or its metabolic byproducts provide nucleation sites which allow the carbonate molecules to become particularly aligned in order to promote mineralization) (Northup \& Lavoie, 2001; Jones, 2010). The bacterial surface (S-layers, specific proteins) has been suggested as possible nucleation sites that are probably just a side effect of their shape (Van Lith et al., 2003; Dupraz et al., 2004; Aloisi et al., 2006). These peculiarities can explain why some strains in a species are able to promote crystal formation and others not. Many of the isolates can contribute to the calcite deposition in the cave, and some of them seem to participate actively in the type of precipitate formed. Calcite is the mineral precipitated in all crystals detected and they present

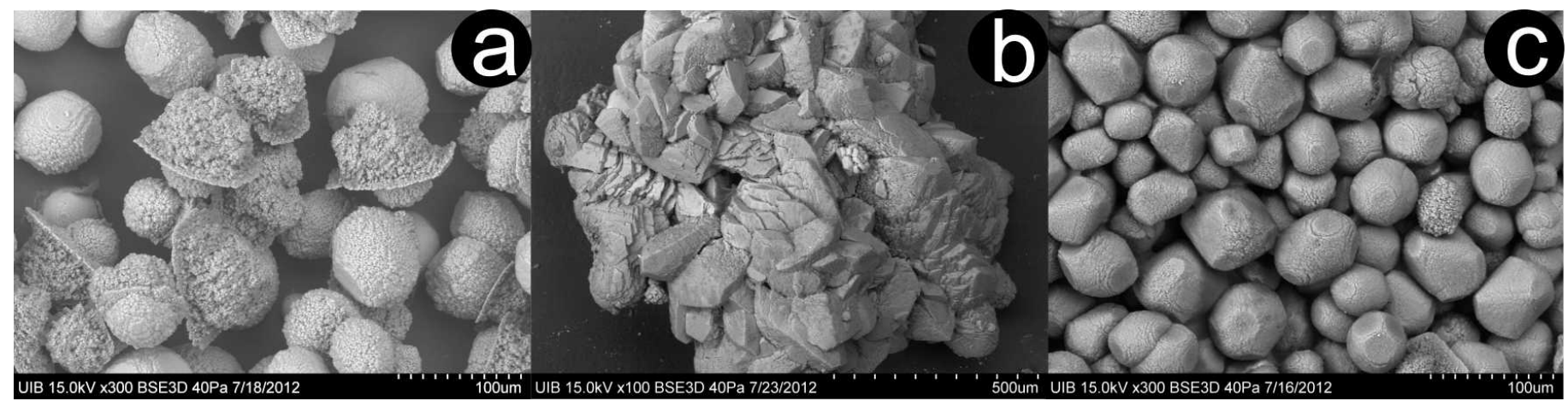

Fig. 6. SEM image of crystal precipitates. Struvite was found only with calcite in the precipitates of Pseudomonas xanthomarina isolates (a) or exclusively in the case of Aspergillus oryzae (b); c) SEM image of calcite precipitates from Nocardioides luteus isolates, sampled in the multicolored deposits. 
high morphological differences in their external crystal growth shape, even when promoted by the same microbial strain. The most abundant bacterial species forming crystals described in the present study have been also detected by other authors (Cacchio et al., 2004; Schaberieter et al., 2004). Most precipitates were calcite crystals, but struvite was formed by 2 strains, 1 of Aspergillus and 1 of $P$. xanthomarina, which was the second most abundant species isolated in sample A1. No other strain of $P$. xanthomarina was able to form crystals, a strain-specific property that has to be studied in more detail.

The bacterial community detected in the multicolored precipitates was totally different. In one of the samples collected only Nocardiodes strains were detected. In the second rock sample, $P$. benzenivorans was present and other strains of these species were scarcely detected in the water samples. These differences in the bacterial communities in the water and in the mineral crusts and scattered mineralizations that represent the multicolored deposits over the rock surface can be explained by the different nature of the habitat, related with the vent morphologies and composed by a substrate that is dominated by a Fe-Mn composition (Merino et al., 2009; Fornós et al., 2011). In contrast to these results, in the study of Northup et al. (2003) by a culture-independent method, the bacterial community on ferromanganese deposits at Lechuguilla cave was dominated by clones of mesophilic Archaea and lactobacilli.

To our knowledge, this is the first report on the identification at the species level of cultured bacterial strains isolated from anchialine waters. A limited number of studies have looked at culturable bacterial populations in cave environments (Ikner et al., 2007; Seymour et al., 2007; Gonzalez et al., 2011; Krstulović et al., 2013) and more recent investigations have been performed by a different approach, using culture-independent methods. Although the analysis of species in the bacterial community along the cave was not exhaustive, the bacterial populations present in these brackish waters are similar to those found in other karst environments. Ikner et al. (2007) detected by culture-based methods mainly Actinobacteria and Proteobacteria, but also Firmicutes, a species not detected in our samples. In the molecular survey performed by Pasic et al. (2010) members of the Gammaproteobacteria were most abundant in the clone libraries, followed in abundance by members of Actinobacteria. Proteobacteria predominated also in the study of Shabarova \& Pernthaler (2010).

As this type of littoral karst cave of Mallorca represents a natural laboratory observation, we will use a long term project to highlight the microbial role in carbonate precipitation/dissolution of speleothems and carbonate rocks.

\section{ACKNOWLEDGEMENTS}

This research was funded by the Spanish Ministry of Economy and Innovation (MINECO) projects CGL2010-18616, CGL2011-24318 and Consolider CSD2009-00006, as well as funds for competitive research groups from the Government of the Balearic Islands (the last two funds with FEDER cofounding). The authors would like to thank Drs. Ferran Hierro, Joan Cifre and Rosa Gomila (Serveis Cintificotècnics, Universitat de les Illes Balears) for their support while conducting the mineral and the WC MALDI TOF analyses. Thanks are debt to Federació Balear d'Espeleologia and to the Direcció General de Biodiversitat del Govern de les Illes Balears by bringing help and the corresponding legal permissions respectively. The authors are grateful to J. Ginés for his help during the water sampling and B.P. Onac for suggestions and proofreading an early version of the manuscript and three anonymous reviewers for their constructive comments.

\section{REFERENCES}

Aloisi G., Gloter A., Krüger M., Wallmann K., Guyot F. \& Zuddas P., 2006 - Nucleation of calcium carbonate on bacterial nanoglobules. Geology, 34: 1017-1020. http://dx.doi.org/10.1130/G22986A.1

Amann R.I., Binder B.J., Olson R.J., Chisholm S.W., Devereux R. \& Stahl D.A., 1990 - Combination of $16 S$ rRNA-Targeted oligonucleotide probes with flow cytometry for analyzing mixed microbial populations. Applied and Environmental Microbiology, 56 (6): 1919-1925.

Banks E.D., Taylor N.M., Gulley J., Lubbers B.R., Giarrizo J.G., Bullen H.A., Hoehler T.M. \& Barton H.A., 2010 - Bacterial calcium carbonate precipitation in cave environments: a function of calcium homeostasis. Geomicrobiology Journal, 27: 444-454.

http://dx.doi.org/10.1080/01490450903485136

Barrón C. \& Duarte C.M., 2009 - Dissolved organic matter release in a Posidonia oceanica meadow. Marine Ecology Progress Series, 374: 75-84. http://dx.doi.org/10.3354/meps07715

Barton H.A. \& Northup D.E., 2007 - Geomicrobiology in cave environments: past, current and future perspectives. Journal of Cave and Karst Studies, 69 (1): 163-178.

Boquet E., Boronat A. \& Ramos-Cormenzana A., 1973 Production of calcite (calcium carbonate) crystals by soil bacteria is a general phenomenon. Nature, 246: 527-529. http://dx.doi.org/10.1038/246527a0

Bosak T., Souza-Egipsy V. \& Newman K., 2004 - A laboratory model for abiotic peloid formation. Geobiology, 2: 189-198. http://dx.doi.org/10.1111/j.1472-4677.2004.00031.x

Cacchio P., Contento R., Ercole C., Cappuccio G., Martinez M.P. \& Lepidi A., 2004 - Involvement of microorganisms in the formation of carbonate speleothems in the Cervo Cave (L'Aquila-Italy). Geomicrobiology Journal, 21: 497509. http://dx.doi.org/10.1080/01490450490888109 Cailleau G., Braissant O., Dupraz C., Aragno M. \& Verrecchia E.V., 2005. - Biologically induced accumulation of $\mathrm{CaCO}_{3}$ in orthox soils of Biga, Ivory Coast. Catena, 59: 1-17.

http://dx.doi.org/10.1016/j.catena.2004.06.002

Castanier S., Le Métayer-Levrel G. \& Perthuisot J.P., 1999 - Ca-carbonate precipitation and limestone genesis-the microbiologist point of view. Sedimentary Geology, 126: 9-23. http://dx.doi.org/10.1016/S0037-0738(99)00028-7

Daims H., Brühl A., Amann R., Schleifer K.H. \& Wagner M., 1999 - The domain-specific probe EUB338 is insufficient for the detection of all Bacteria: development and evaluation of a more comprehensive probe set. Systematic and Applied Microbiology, 22: 434-444. http://dx.doi.org/10.1016/S0723-2020(99)80053-8 
Dorale J.A., Onac B.P., Fornós J.J., Ginés J., Ginés A., Tuccimei P. \& Peate D.W., 2010 - Sea-level 81,000 years ago in Mallorca. Science, 327: 860-863. http://dx.doi.org/10.1126/science.1181725

Dupraz C., Visscher P.T., Baumgartner L.K. \& Reid R.P., 2004 - Microbe-mineral interactions: early carbonate precipitation in a hypersaline lake (Eleuthera Island, Bahamas). Sedimentology, 51: 745-765. http://dx.doi.org/10.1111/j.1365-3091.2004.00649.x

Ehrlich H.L., 2002 - Geomicrobiology (4th ed.) New York: Marcel Dekker, Inc.

Fairchild I.J. \& Baker A., 2012 - Speleothem science. From process to past environments. Wiley Blackwell. http://dx.doi.org/10.1002/9781444361094

Felsenstein J., 1989 - PHYLIP-phylogeny inference package (version 3.0). Cladistics, 5: 164-166.

Fernández-Díaz L., Putnis A., Prieto M. \& Putnis C.V., 1996 - The role of magnesium in the crystallization of calcite and aragonite in a porous medium. Journal of Sedimentary Research, 66: 482-491.

Fornós J.J., Merino A., Ginés J., Ginés A. \& Gràcia F., 2011 - Solutional features and cave deposits related to hypogenespeleogenetic processes in a littoral cave of Mallorca Island (western Mediterranean). Carbonates and Evaporites, 26 (1): 69-81. http://dx.doi.org/10.1007/s13146-010-0040-3

Fornós J.J., Pomar L. \& Ramos Guerrero E., 2002 - Balearic Islands. In: Gibbons W. \& Moreno T. (Eds.), The Geology of Spain. London: The Geological Society: 327-334.

Ginés A. \& Ginés J., 1986 - On the interest of speleochronological studies in karstified islands. The case of Mallorca (Spain). Proceedings of the 9th International Congress of Speleology, Barcelona, 1: 297-300.

Ginés A., Ginés J., Gómez-Pujol L., Onac B.P. \& Fornós J.J. (Eds.), 2012 - Mallorca: a Mediterranean benchmark for Quaternary studies. Monografies de la Societat d'Història Natural de les Balears, 18. Palma de Mallorca, 219 p.

Ginés J., Ginés A., Fornós J.J., Merino A. \& Gràcia F. 2009a - About the genesis of an exceptional coastal cave from Mallorca Island (Western Mediterranean). The lithological control over the pattern and morphology of Cova des Pas de Vallgornera. In: White W.B. (Ed.), Proceedings of the $15^{\text {th }}$ International Congress of Speleology. Kerville: National Speleological Society, 1: 481-487.

Ginés J., Ginés A., Fornós J.J., Merino A. \& Gràcia F., $2009 \mathrm{~b}$ - On the role of hypogene speleogenesis in shaping the coastal endokarst of southern Mallorca (western Mediterranean). In: Klimchouk A.B. \& Ford D.C. (Eds.), Hypogene speleogenesis and karst hydrogeology of artesian basins. Ukrainian Institute of Speleology and Karstology, Special Paper 1, Simferopol, Ukraine: 91-99.

Ginés J., Fornós J.J., Ginés A., Merino A. \& Gràcia F., 2014 - Geologic constraints and speleogenesis of Cova des Pas de Vallgornera, a complex coastal cave from Mallorca Island (Western Mediterranean). International Journal of Speleology, 43 (1): 105-124 http:/ /dx.doi.org/10.5038/1827-806X.43.2.2

Gomila M., Gascó J., Busquets A., Gil J., Bernabeu R., Buades J.M. \& Lalucat J., 2005 - Identification of culturable bacteria present in haemodialysis water and fluid. FEMS Microbiology Ecology, 52: 101-114. http://dx.doi.org/10.1016/j.femsec.2004.10.015

Gonzalez B.C., Iliffe T.M., Macalady J.L., Schaperdoth I. \& Kakuk B., 2011 - Microbial hotspots in anchialine blueholes: initial discoveries from the Bahamas. Hydrobiologia, 677: 149-156.

http://dx.doi.org/10.1007/s10750-011-0932-9

Gràcia F., Fornós J.J., Clamor B., Febrer M. \& Gamundí, P., 2007 - La cova de sa Gleda I. Sector Clàssic, Sector de Ponent $i$ Sector Cinc-cents. (Manacor, Mallorca): Geomorfologia, espeleogènesi, sedimentologia $i$ hidrologia. Endins, 31: 43-96.
Gràcia F., Fornós J.J., Gamundí P., Clamor B., Pocoví J. \& Perelló M.A., 2009 - Les descobertes subaqaàtiques a la Cova des Pas de Vallgornera (llucmajor, Mallorca): Història $i$ descripció dels descobriments, hidrologia, espeleotemes, sediments, paleontología i fauna. Endins, 33: 35-72.

Gràcia F., Ginés J., Pons G.X., Ginard A. \& Vicens D. (Eds.), 2011 - El carst, patrimoni natural de les Illes Balears. Endins, 35 / Monografies de la Societat d'Història Natural de les Balears, 17, 368 p.

Gray C.J. \& Engel A.S., 2013 - Microbial diversity and impact on carbonate geochemistry across a changing geochemical gradient in a karst aquifer. The ISME Journal, 7: 325-337. http://dx.doi.org/10.1038/ismej.2012.105

Jones B., 2010 - Microbes in caves: agents of calcite corrosion and precipitation. In: Pedley H.M. \& Rogerson M. (Eds.), Tufas and speleothems: Unravelling the microbial and physical controls. Geological Society, London, Special Publication, 336: 7-30.

Jukes T.H. \& Cantor C.R., 1969 - Evolution of protein molecules. In: Munro H.N. (Ed.), Mammalian protein metabolism. New York: Academic Press: 21-132. http://dx.doi.org/10.1016/B978-1-4832-3211-9.50009-7

Kemp P.F. \& Aller J.Y., 2004 - Estimating prokaryotic diversity: when are 16S rDNA libraries large enough? Limnology and Oceanography Methods, 2: 114-125. http://dx.doi.org/10.4319/lom.2004.2.114

Krstulović N., Šolić M., Šantić D., Maršić-Lucić J., Ordulf M. \& Šestanović S., 2013 - Microbial community structure in two anchialine caves on Mljet Island (Adriatic Sea). Acta Adriatica, 54 (2): 183-198.

Lace M.J. \& Mylroie J.E. (Eds.), 2013 - Coastal karst landforms. Coastal Research Library, 5. Springer, Berlin. http:/ / dx.doi.org/10.1007/978-94-007-5016-6

Lane D.J., 1991 - 16S/23S rRNA sequencing. In: Stackebrandt E. \& Goodfellow M. (Eds.), Nucleic acid techniques in bacterial systematics. John Wiley \& Sons, 115-175.

Manz W., Amann R., Ludwig W., Wagner M. \& Schleifer K.H., 1992 - Phylogenetic oligodeoxynucleotide probes for the major subclasses of proteobacteria: problems and solutions. Systematic and Applied Microbiology, 15: 593-600. http:/ /dx.doi.org/10.1016/S0723-2020(11)80121-9

Medlin L., Elwood H.J., Stickel S. \& Sogin M.L., 1988 - The characterization of enzymatically amplified eukaryotic 16S-like rRNA-coding regions. Gene, 71: 491-499. http://dx.doi.org/10.1016/0378-1119(88)90066-2

Melim L.A., Liescheidt R., Northup D.E., Spilde M.N., Boston P.J. \& Queen J.M., 2009 - A biosignature suite from cave pool precipitates, Cottonwood Cave, New Mexico. Astrobiology, 9 (9): 907-917. http://dx.doi.org/10.1089/ast.2009.0345

Merino A., Fornós J.J. \& Onac B.P., 2009 - Preliminary data on mineralogical aspects of cave rims and vents in Cova des Pas de Vallgornera, Mallorca. In: White W.B. (Ed.), Proceedings of the $15^{\text {th }}$ International Congress of Speleology. Kerrville: National Speleological Society, 1: 307-311.

Merino A., Fornós J.J. \& Ginés A., 2011a - Espeleotemes i minerals de les coves de Mallorca. In: Gràcia F., Ginés J., Pons G.X., Ginard A. \& Vicens, D. (Eds.), El carst, patrimoni natural de les Illes Balears. Endins, 35 / Monografies de la SocIetat d'Història Natural de les Balears, 17:183-198.

Merino A., Mulet A., Mulet G., Croix A., Kristofersson A., Gràcia F. \& Perelló M.A., 2014a - History and description of Cova des Pas de Vallgornera, (Mallorca, Spain): history of exploration and cave description. International Journal of Speleology, 43 (2): 95-104. http://dx.doi.org/10.5038/1827-806X.43.2.1 
Merino A., Mulet A., Mulet G., Croix A., Kristofersson A., Gràcia F., Ginés J. \& Fornós J.J., 2011b - La Cova des Pas de Vallgornera (Llucmajor, Mallorca). La cova de major desenvolupament de les Illes Balears. Endins, 35 / Monografies de la Societat d'Història Natural de les Balears, 17: 147-164.

Merino A., Ginés J., Tuccimei P., Soligo M. \&, Fornós J.J., 2014b - Speleothems in Cova des Pas de Vallgornera: their distribution and characteristics within an extensive coastal cave from the eogenetic karst of southern Mallorca (Western Mediterranean). International Journal of Speleology, 43 (2): 125-142.

http://dx.doi.org/10.5038/1827-806X.43.2.3

Northup D.E., Barns S.M., Yu L.E., Spilde M.N., Schelble R.L.T., Dano K.E., Crossey L.J., Connolly C.A., Boston P.J., Natvig D.O. \& Dahm C.N. 2003 - Diverse microbial communities inhabiting ferromanganese deposits in Lechuguilla and Spider caves. Environmental Microbiology, 5:1071-1086.

Northup D.E. \& Lavoie K.H., 2001 - Geomicrobiology of caves: a review. Geomicrobiology Journal, 18: 199-222. http:/ /dx.doi.org/10.1080/01490450152467750

Onac B.P., Fornós J.J., Merino A., Ginés J. \& Diehl J., 2014 - Linking mineral deposits to speleogenetic processes in Cova des Pas de Vallgornera (Mallorca, Spain). International Journal of Speleology, 43 (2): 143-157. http://dx.doi.org/10.5038/1827-806X.43.2.4

Page R.D.M., 1996 - TREEVIEW: an application to display phylogenetic trees on personal computers. Computer Applications in the Biosciences 12: 357-358.

Pasic L., Kovce B., Sket B. \& Herzog-Velikonja B., 2010 - Diversity of microbial communities colonizing the walls of a karstic cave in Slovenia. FEMS Microbiology Ecology, 71: 50-60. http://dx.doi.org/10.1111/j.1574-6941.2009.00789.x

Pomar L., 1991 - Reef geometries, erosion surfaces and high-frequency sea-level changes, upper Miocene Reef Complex, Mallorca, Spain. Sedimentology, 38: 243-269. http://dx.doi.org/10.1111/j.1365-3091.1991.tb01259.x

Pomar L., Ward W.C. \& Grenn D.G., 1996 - Upper Miocene reef. Complex of the Llucmajor area, Mallorca, Spain. In: Franseen E., Esteban M., Ward, W.C. \& Rouchy J.M. (Eds.), Models for carbonate stratigraphy from Miocene reef complexes of the Mediterranean regions. SEPM Concepts in Sedimentology and Paleontology, 5: 191-225.

Porter K. \& Feig Y., 1980 - The use of DAPI for identifying and counting aquatic microflora. Limnology and Oceanography, 25: 943-948.

http://dx.doi.org/10.4319/10.1980.25.5.0943

Reasoner D.J. \& Geldreich E.E. 1985 - A new medium for the enumeration and subculture of bacteria from potable water. Applied Environmental Microbiology, 49: 1-7.

Rivadeneyra M.A., Párraga J., Delgado R., RamosCormenzana A. \& Delgado G., 2004 - Biomineralization of carbonates by Halobacillus trueperi in solid and liquid media with different salinities. FEMS Microbiology Ecology, 48: 39-46. http://dx.doi.org/10.1016/j.femsec.2003.12.008

Sánchez-Navas A. \& Martín-Algarra A., 2001 - Genesis of apatite in phosphate stromatolites. European Journal of Mineralogy, 13: 361-376.

http://dx.doi.org/10.1127/0935-1221/01/0013-0361
Shabarova T. \& Pernthaler J., 2010 - Karst pools in subsurface environments: collectors of microbial diversity or temporary residence between habitat types. Environmental Microbiology, 14: 1061-1074.

http://dx.doi.org/10.1111/j.1462-2920.2009.02151.x

Schabereiter-Gurtner C., Saiz-Jimenez C., Piñar G., Lubitz W. \& Rölleke S., 2004 - Phylogenetic diversity of bacteria associated with Paleolithic paintings and surrounding rock walls in two Spanish caves (Llonin and La Garma). FEMS Microbiology Ecology, 47: 235-247.

http:/ /dx.doi.org/10.1016/S0168-6496(03)00280-0

Seymour J.R., Humpherys W.F. \& Mitchell, J.G., 2007 Stratification of the microbial community inhabiting an anchialine sinkhole. Aquatic Microbial Ecology, 50: 1124. http://dx.doi.org/10.3354/ame01153

Sket B., 2005 - Anchialine caves. In: Culver D.C. \& White W.B. (Eds.) - Encyclopedia of Caves. Elsevier Academic Press: 30-37.

Thompson J.D., Gibson T.J., Plewniak F., Jeanmougin F. \& Higgins D.G., 1997 - The CLUSTAL_X Windows interface: flexible strategies for multiple sequence alignment aided by quality analysis tools. Nucleic Acids Research, 25: 4876-4882. http://dx.doi.org/10.1093/nar/25.24.4876

Tuccimei P., Ginés J., Delitala M.C., Ginés A., Gràcia F., Fornós J.J. \& Taddeucci, A., 2006 - Last interglacial sea level changes in Mallorca Island (western Mediterranean). High precision $U$-series data from phreatic overgrowths on speleothems. Zeitschrift für Geomorphologie, 50 (1): 1-21.

Tucker M.E. \& Wright V.P., 1990 - Carbonate sedimentology. Blackwell. http:/ / dx.doi.org/10.1002/9781444314175

Van Lith Y., Warthmann R., Vasconcelos C. \& McKenzie J., 2003 - Microbial fossilization in carbonate sediments: a result of the bacterial surface involvement in dolomite precipitation. Sedimentology, 50: 237-245. http://dx.doi.org/10.1046/j.1365-3091.2003.00550.x

Van Lith Y., Warthmann R., Vasconcelos C. \& McKenzie J.A., 2003 - Sulphate-reducing bacteria and dolomite/ calcite formation sulphate-reducing bacteria induce lowtemperature Ca-dolomite and high $\mathrm{Mg}$-calcite formation. Geobiology, 1: 71-79.

http://dx.doi.org/10.1046/j.1472-4669.2003.00003.x Wilson K., 1987 - Preparation of genomic DNA from bacteria. In: Ausubel F. M., Brent R., Kingston R. E., Moore D. D., Seidman J. G., Smith J. A. \& Struhl K. (Eds.), Current protocols in molecular biology. John Wiley \& Sons, New York: 241-242.

Wilson W.L. \& Morris T.L., 1994 - Cenote Verde: a meromictic karst pond, Quintana Roo, Mexico. In: Sasowsky I.D, Palmer M.V, (Eds.). Breakthroughs in karst geomicrobiology and redox geochemistry: Abstracts and field-trip guide for the symposium held February 16 through 19, 1994, Colorado Springs, Colorado. Charles Town, WV: Karst Waters Institute: Special Publication 1: 77-79.

Welker M. \& Moore E.R.B., 2011 - Applications of wholecell matrix-assisted laser- desorption/ionization timeof-flight mass spectrometry in systematic microbiology. Systematic and Applied Microbiology, 34: 2-11. http://dx.doi.org/10.1016/j.syapm.2010.11.013 